\title{
Economic analysis and marketing margin of pistachios in Turkey
}

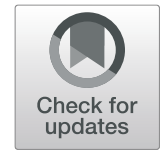

Emine AŞKAN

\begin{abstract}
Background: In this study, producer and consumer prices and the marketing structure of pistachios in Turkey were examined. Between 2003 and 2017, production, consumption, foreign trade, price fluctuations, and marketing were emphasized. It was determined that the number of fruit trees in pistachios increased. According to current and real prices, pistachio marketing margins are calculated, and producer and consumer chain indexes are calculated according to current prices and compared with annual inflation rates. Supply and demand models related to pistachio were estimated and interpreted statistically.

Results: As a result, the real price of walnut and periodicity on the amount of pistachio production, on the consumption of Pistachio, the costumer real price of pistachio, population, and periodicity were determined to be effective.

Conclusion: Demand elasticity in pistachio (1.055) was found to be greater than supply elasticity (0.306), and consumers' sensitivity to price changes was much higher than that of producers.
\end{abstract}

Keywords: Pistachio, Marketing structure, Price fluctuations

\section{Introduction}

Pistachio (in Turkish Antep Fisttğı) is an edible fruit and the tree that it grows on is from cashew family (Anacardiaceae). This tree takes its name from the city Gaziantep where it commonly grows. Pistachio ingredients are $22.6 \%$ protein, $15.6 \%$ carbohydrate, and 3250 calories when it is compared with fat-containing fruits. It is in the second rank after the hazelnut in terms of fat. Since the high nutrition rate and as a cookie that is generally consumed, the pistachio can find purchaser both in domestic and foreign markets (Republic of Turkey Ministry of National Education 2015).

Pistachio is a fruit which tends to periodicity. Trees give little fruits or no fruit after the productive year. (Ertürk et al. 2015). Since the periodicity, production quantity changes year after year.

The production of the pistachio in 770,861 ha is 1,115 , 066 tonnes in the whole world in 2017. Iran is the leader producer with the share of $51.57 \%$. Iran is in the first rank with the production of 574,987 tonnes in 429,535 ha area with the 1.339 tonnes/ha productivity rate. The

Correspondence: emine.askan@igdir.edu.tr

Department of Agricultural Economics, Faculty of Agriculture, Iğdır University, Şehit Bülent Yurtseven Campus, 76000 Igdir, Turkey
USA is second in the ranking with the 272,291 tonnes of production in 101,171-ha area with the 2.69 tonnes/ha productivity with the $24.42 \%$ share. While China is getting 95,294 tonnes of pistachio from an area of 30,077 ha with 3.17 tonnes/ha productivity, Turkey is at the fourth rank with its fluctuating production structure with the 78,000 tonnes of harvest in an area of 68,237-ha land and 1.14 tonnes/ha rate. (Food and Agriculture Organization 2019).

Since the Iranian origin pistachio's price is relatively low and the seeds are large with high-level splitting range, those pistachios are demanded worldwide. The pistachio which grows in China is from a different family; thus, it is not proper for the human consumption. In the last few years in China, producing of pistachio has been given weight but this plant is cultivated for biodiesel purposes (Pistachio Sector Report, Republic of Turkey Ministiry of Trade 2016).

Although Turkey originated smaller pistachios and their price is high, the taste is more intense and thus it gains advantage in the international market. It is evaluated that stressing this merit in marketing is important. As evidence to this, the USA became an importer in Turkish origin pistachio in recent years which shows 
that this merit has to be stated (Pistachio Sector Report, Republic of Turkey Ministiry of Trade 2016).

According to the 2016 data, pistachio export globally reached to the $\$ 2.811$ billion. While the USA is the first in ranking with the rate $32.22 \%$ ( $\$ 1.084$ billion), Iran is the second with the rate $24.43 \%$ (\$686 million). Turkey ranked seventh (\$66 million) with the 2.37\% (Food and Agriculture Organization 2019).

According to the 2016 data, Hong Kong, China is ranked as first with the $25.20 \%$ and $\$ 721.5$ million worth of import which globally reaches $\$ 2.863$ billion. Germany $12.82 \%$ (\$367.1 million), Vietnam $12.08 \%$ (\$345.8 million), and Italy 4.67\% (\$133.8 million) come after China respectively. Turkey has the share $0.02 \%$ in importing countries with the worth of $\$ 496,000$ (Food and Agriculture Organization 2019).

According to the Turkish Statistical Institute 2017 data, Gaziantep has 136,347-ha area for the pistachio with a share of $41.47 \%$. Sanlıurfa follows Gaziantep with the 25,809 ha (7.85\%), and Adiyaman 18,807 ha (5.72\%) and Siirt respectively. $93.18 \%$ of the total production is produced in Gaziantep, Şanlıurfa, Adıyaman, and Siirt. In total, Şanlıurfa is ranked as first with the rate of $36.55 \%$ with 28,507 tonnes, and Gaziantep produces 14,762 tonnes with the rate of $18.92 \%$ (Turkish Statistical Institute 2019).

In this study, both economic analyses have been done by taking into account the producer-consumer figures, and marketing situation is analyzed. Additionally, factors that have effect on pistachio supply and demand are determined by estimating models of supply and demand functions of the pistachio.

\section{Materials and methods Materials}

In this study while production quantity, number of the trees, productivity, manufacturer, and consumer prices annual data, in the 2003-2017 period, obtained from Turkish Statistical Institute (TSI) web site, exportimport amounts are from Food and Agriculture Organization (FAO) and Agricultural Economic and Policy Development Institute (AEPDE). Price of the fertilizer, diesel, agricultural labor costs are obtained from TSI and AEPDE (2019). Additionally other sources also used in the study.

\section{Methods}

Producer and consumer current prices of pistachio are converted to real prices by taking $2017=100$. Fluctuations in the prices year by year, at first are shown as absolute values and then stated as percentage of the first in the compared 2 years. Averages are calculated disregard to their sign (Altundağ and Güneș 1992; Dağdemir and Birinci 1999).
Difference between the prices that are obtained by farmers (manufacturer prices) and prices that are paid by consumers (consumer prices) is calculated as marketing margin (Așkan and Dağdemir 2015; Topcu 2003; Topcu 2004).

Chained price index is calculated by comparing manufacturer and consumer prices by taking the 2003-2017 period. In the chain price index, there is no base year. The main goal in the chained price index is analyzing annual changes in the time, in other words, specifying the increase or decrease in the prices in the following year with respect to the former (Dağdemir 1998).

Supply quantities of annual plants are the function of the former year. However, while pistachio is a multi-year plant production, decision cannot be changed. Thus, the production decision of the pistachio is imagined as hypothetically 1-year delay (Özkan et al. 2011:2). While the relation between the producers earning and pistachio production was inquired, it is taken into consideration that the given price of a year $(t)$ could have effect only after a year $(t-1)$ on the production decision; pistachio production series are kept in that vein; price series are analyzed counted by 1 year backwards.

While the supply and demand function models are estimated, series are proved one by one with linear, $\log -\log$ and semi-log models. Linear models (Lin-Lin) are used which givesthe best results in analysis. Prices in all independent variables are taken into consideration as real prices $(2017=100)$. In the models formed in order to understand if there is an autocorrelation problem which can be seen in time series analysis, Durbin-Watson test is implemented and no autocorrelation problem is detected.

Model which is estimated for pistachio supply function is at the formula 1 .

$$
\begin{aligned}
\mathrm{PP}_{(t)}: & \alpha+\beta_{1} \mathrm{PPP}_{(t-1)}+\beta_{2} \mathrm{HPP}_{(t-1)} \\
& +\beta_{3} \mathrm{WPP}_{(t-1)}+\beta_{4} \mathrm{FP}_{(t)}+\beta_{5} \mathrm{LP}_{(t)} \\
& +\beta_{6} \mathrm{DP}_{(t)}+\beta_{7} T_{(t)}+\beta_{8} P_{(t)}+\epsilon
\end{aligned}
$$

PP: Pistachio Production Quantity (tonnes)

PPP: Pistachio Producer Real Price $(\notin / \mathrm{kg})$

HPP: Hazelnut (shelled) Producer Real Price $(€ / \mathrm{kg})$

WPP: Walnut (shelled) Producer Real Price $(€ / \mathrm{kg})$

FP: Fertilizer Real Price (‡/ton)

LP: Agricultural Labour Real Price ( $\notin /$ day)

DP: Diesel Real Price $(€ / \mathrm{t})$

T: Trend (years 2003-3017; 1,2,3, ... 15)

P: Periodicity ${ }^{1}$ (high productivity year: 1 , low productivity year: 0 )

${ }^{1}$ Technical definition of fruit species and varieties which yield fruit for 1 year and give little or no fruit in the following year. In other words, different productivity from 1 year to other year. 
Model which is estimated for the pistachio supply function is at the formula 2 .

$$
\begin{aligned}
\mathrm{PC}_{(t)}: & \alpha+\beta_{1} \mathrm{PCP}_{(t)}+\beta_{2} \mathrm{HCP}_{(t)}+\beta_{3} \mathrm{WCP}_{(t)} \\
& +\beta_{4} \mathrm{NP}_{(t)}+\beta_{5} \mathrm{NI}_{(t)}+\beta_{6} T_{(t)}+\beta_{7} P_{(t)} \\
& +\epsilon
\end{aligned}
$$

PC: Pistachio Consumption Amount (tonnes) (production + Import - Export)

PCP: Pistachio Consumer Real Price $(€ / \mathrm{kg})$

HCP: Hazelnut (shelled) Consumer Real Price $(\notin / \mathrm{kg})$

WCP: Walnut (shelled) Consumer Real Price $(£ / \mathrm{kg})$

NP: Population (person)

NI: National Income ( $\notin /$ person) (converted to real income)

P: Periodicity (high productivity year: 1 , low productivity year: 0 )

\section{Results}

Between 2003 and 2017, the number of the fruitful tree increased $81.62 \%$. Since the pistachio is a fruit which tends to periodicity, production quantity and productivity fluctuate year by year (Table 1). In the 15-year period, average annual production is 101,062 tonnes; average productivity per tree is $3.04 \mathrm{~kg}$.

Between 2003 and 2017 while it can be seen, fluctuations in the consumption in pistachio, as a trend, an increase can be seen. In the 15-year period average annual consumption is calculated as $1.34 \mathrm{~kg}$. Pistachio import is so small that can be negligible. While the export level has fluctuations, it increased year by year (Table 2).

In general, pistachio current prices are tend to increase despite fluctuations. Between 2003 and 2017, producer prices increased approximately 281\% (3.81 times), and consumer prices increased 376\% (4.76 times). In current prices, consumer prices increased more than the producer prices (Table 3).

Difference between the prices that are obtained by farmers (manufacturer prices) and prices that are paid by consumers (consumer prices) is called marketing margin. It is the yield that is obtained by commissioners. According to current prices, while commissioner yield changes between 48.32 and $67.26 \%$, producer yield changes between 32.74 and $51.68 \%$ (Table 3 ).

In general, pistachio real prices are tend to increase despite fluctuations. Between 2003 and 2017, producer real prices increased approximately $22.14 \%$, and consumer real prices increased $59.4 \%$. In real prices, consumer prices increased more than the producer prices. According to real prices, while commissioner yield changes between 45.00 and $67.74 \%$, producer yield changes between 32.26 and $55.00 \%$ (Table 4).

In Table 5, producer- and consumer-chained indexes have been calculated in current prices, and the differences have been taken and compared with the inflation rates. With this comparison, it has been seen that producer yield is above the inflation rate in the years 2009, 2010, and 2014. Just in those years, prices are in favor of producer. When we analyze the consumers' purchasing

Table 1 Fruitful tree number, production, and productivity in Turkey

\begin{tabular}{llll}
\hline Years & $\begin{array}{l}\text { Fruitful tree number } \\
(1000 \text { - adet) }\end{array}$ & $\begin{array}{l}\text { Production } \\
\text { (tonnes) }\end{array}$ & $\begin{array}{l}\text { Productivity } \\
\text { (kg/per tree) }\end{array}$ \\
\hline 2003 & 26,300 & 90,000 & 3.42 \\
2004 & 26,500 & 30,000 & 1.13 \\
2005 & 28,000 & 60,000 & 2.14 \\
2006 & 28,264 & 110,000 & 3.89 \\
2007 & 28,464 & 73,416 & 2.58 \\
2008 & 28,668 & 120,113 & 4.19 \\
2009 & 30,144 & 81,795 & 2.71 \\
2010 & 29,617 & 128,000 & 4.32 \\
2011 & 30,868 & 112,000 & 3.63 \\
2012 & 37,150 & 150,000 & 4.04 \\
2013 & 38,116 & 88,600 & 2.32 \\
2014 & 39,330 & 80,000 & 2.03 \\
2015 & 40,597 & 144,000 & 3.55 \\
2017 & 42,570 & 170,000 & 3.99 \\
Average & 47,766 & 78,000 & 1.63 \\
\hline
\end{tabular}

Source: TSI, 2019 
Table 2 Consumption of pistachio per capita and marketing in Turkey

\begin{tabular}{lllll}
\hline Years & $\begin{array}{l}\text { Import } \\
\text { (tonnes) }\end{array}$ & $\begin{array}{l}\text { Export } \\
\text { (tonnes) }\end{array}$ & $\begin{array}{l}\text { Total consumption } \\
\text { (tonnes) }\end{array}$ & $\begin{array}{l}\text { Consumption per } \\
\text { capital }\end{array}$ \\
\hline 2003 & 68 & 1038 & 89,030 & 1.33 \\
2004 & 120 & 757 & 29,363 & 0.43 \\
2005 & 37 & 823 & 59,214 & 0.86 \\
2006 & 79 & 864 & 109,215 & 1.57 \\
2007 & 84 & 975 & 72525 & 1.03 \\
2008 & 84 & 2621 & 1.64 \\
2009 & 197 & 2376 & 117,576 & 1.10 \\
2010 & 14 & 717 & 79,616 & 1.73 \\
2011 & 10 & 1160 & 127,297 & 1.48 \\
2012 & 0 & 2328 & 110,850 & 1.95 \\
2013 & 266 & 3948 & 147,672 & 1.11 \\
2014 & 15 & 821 & 84,918 & 1.02 \\
2015 & 15 & 3154 & 79,194 & 1.79 \\
2016 & 29 & 4710 & 140,861 & 2.07 \\
Average & 8 & 2706 & 165,319 & 0.93 \\
\hline
\end{tabular}

Source: FAO, 2019; TSI, 2019

power for pistachio, while in 2005, 2009, 2010, and 2014, consumers' purchasing power decreased; in other years, it increased.

According to the signs which are estimated in the model for the pistachio supply function, there is a linear relationship among the hazelnut producer real price, fertilizer real price, diesel real price, trend (time), and periodicity; and there is an adverse relationship between walnut producer real price and agricultural laborer price. Additionally, it can be seen that there is a linear relationship among the pistachio production and hazelnut producer real price, fertilizer real price, and diesel real price. This situation

Table 3 According to current prices: marketing margin in Turkey

\begin{tabular}{llllll}
\hline Years & $\begin{array}{l}\text { Producer prices } \\
(\boldsymbol{\Xi} / \mathrm{kg})\end{array}$ & $\begin{array}{l}\text { Consumer prices } \\
(\boldsymbol{E} / \mathrm{kg})\end{array}$ & Marketing margin & $\begin{array}{l}\text { Producer yield } \\
(\%)\end{array}$ & $\begin{array}{l}\text { Commissioner yield } \\
(\%)\end{array}$ \\
\hline 2003 & 5.01 & 12.25 & 7.24 & 40.87 & 59.13 \\
2004 & 6.03 & 11.67 & 5.64 & 45.34 & 48.32 \\
2005 & 6.23 & 13.73 & 7.51 & 41.25 & 54.66 \\
2006 & 6.53 & 15.82 & 9.29 & 45.67 & 58.75 \\
2007 & 6.99 & 15.32 & 8.32 & 39.31 & 54.33 \\
2008 & 6.81 & 17.32 & 10.51 & 40.33 & 60.69 \\
2009 & 7.85 & 19.46 & 11.61 & 42.25 & 59.67 \\
2010 & 11.07 & 26.20 & 15.13 & 42.67 & 57.75 \\
2011 & 11.19 & 26.21 & 15.03 & 37.67 & 57.33 \\
2012 & 10.08 & 26.76 & 16.68 & 37.89 & 62.33 \\
2013 & 11.23 & 29.63 & 18.40 & 39.87 & 62.11 \\
2014 & 19.12 & 47.96 & 28.83 & 34.02 & 60.13 \\
2015 & 17.46 & 51.32 & 33.86 & 33.61 & 65.98 \\
2016 & 15.79 & 46.97 & 31.18 & 32.74 & 66.39 \\
2017 & 19.09 & 58.31 & 39.22 & 67.26
\end{tabular}


Table 4 Pistachio marketing margin according to real prices in Turkey $(2017=100)$

\begin{tabular}{llllll}
\hline Years & $\begin{array}{l}\text { Producers prices } \\
(/ \mathrm{kg})\end{array}$ & $\begin{array}{l}\text { Consumer prices } \\
(/ \mathrm{kg})\end{array}$ & Marketing margin & $\begin{array}{l}\text { Producers income } \\
(\%)\end{array}$ & $\begin{array}{l}\text { Commissioners income } \\
(\%)\end{array}$ \\
\hline 2003 & 15.63 & 36.58 & 20.95 & 42.73 & 57.27 \\
2004 & 17.33 & 31.51 & 14.18 & 55.00 & 45.00 \\
2005 & 16.55 & 34.26 & 17.72 & 48.29 & 51.71 \\
2006 & 15.82 & 35.96 & 20.14 & 44.00 & 56.00 \\
2007 & 15.59 & 32.74 & 17.15 & 47.62 & 52.38 \\
2008 & 13.74 & 32.84 & 19.11 & 41.83 & 58.17 \\
2009 & 14.91 & 36.45 & 21.54 & 40.90 & 59.10 \\
2010 & 19.37 & 45.24 & 25.87 & 42.81 & 57.19 \\
2011 & 18.38 & 40.74 & 22.36 & 45.12 & 54.88 \\
2012 & 15.21 & 39.21 & 23.99 & 38.80 & 61.20 \\
2013 & 15.76 & 41.55 & 25.78 & 37.94 & 62.06 \\
2014 & 24.66 & 60.99 & 36.33 & 40.43 & 59.57 \\
2015 & 20.92 & 62.00 & 41.08 & 33.74 & 66.26 \\
2016 & 17.55 & 54.40 & 36.85 & 32.26 & 67.74 \\
\hline
\end{tabular}

Source: Authors' own calculations

does not fit with the economics theory. After using the time series data, it is possible to occur adverse results for the economics theory in the signs of the coefficients.

In the model while $R^{2}$ value is high (0.952), in the $F$ test, pistachio supply function model is statistically significant in the $1 \%(P=0.002)$ significance level. Additionally, it is determined that independent variables, walnut producer real prices, and periodicity are statistically significant in $10 \%$ significance level; other independent variables are insignificant.

Results of regression analysis about pistachio supply function

\begin{tabular}{|c|c|c|c|c|c|}
\hline PP & Coefficient & & Standard error & $P(\mathrm{t})$ & $P(F)$ \\
\hline$a$ & 223021 & & 161094 & 0.216 & 0.002 \\
\hline PPP & 1812 & & 1834 & 0.361 & \\
\hline HPP & 12185 & * & 5254 & 0.060 & \\
\hline WPP & -19700 & * & 8594 & 0.062 & \\
\hline FP & 57808 & & 45881 & 0.255 & \\
\hline LP & -4787 & & 3785 & 0.253 & \\
\hline DP & 6541 & & 11670 & 0.595 & \\
\hline $\mathrm{T}$ & 14301 & & 8069 & 0.127 & \\
\hline$P$ & 26620 & * & 12959 & 0.086 & \\
\hline
\end{tabular}

Significant in $* 10 \%, * * 5 \%$, and $* * * 1 \%$ significance level According to the signs which are estimated in the pistachio demand function, there is an adverse relationship among the pistachio consumer and pistachio consumer real price with national income, and there is a linear relationship among the hazelnut consumer real price, walnut consumer real price, population, and periodicity. While it was expected a positive relationship between pistachio consumption and national income, the relationship occurred as negative.

In the model while $R^{2}$ value is high (0.924), in the $F$ test, pistachio demand function model is statistically significant in the $1 \%(P=0.000)$ significance level. Additionally, it is determined that independent variables, pistachio consumer real price, and population in the 5\% significance level and periodicity in the $1 \%$ significance level are statistically significant, other independent variables are insignificant. Periodicity has influence not only in production but also in consumption.

Results of the regression analysis about pistachio demand function

\begin{tabular}{llllll}
\hline PC & Coefficient & & Standard error & $P(\mathrm{t})$ & $P(\mathrm{~F})$ \\
\hline$a$ & -780821 & $* *$ & 259881 & 0.017 & 0.000 \\
PCP & -2442 & $* *$ & 881 & 0.024 & \\
HCP & 611 & & 483 & 0.242 & \\
WCP & 1789 & & 1364 & 0.225 & \\
NP & 15 & $* *$ & 5 & 0.017 & \\
NI & -9 & $*$ & 4 & 0.063 & \\
$P$ & 532826 & $* * *$ & 7426 & 0.000 & \\
\hline
\end{tabular}

Significant in ${ }^{*} 10 \%$, $* 5 \%$, and ${ }^{* * *} 1 \%$ significance level

\section{Discussion}

Aksoy et al. (2002) determined that in the case of Pistachio supply equality, there is a positive relation between pistachio productivity per ha and producer's income $\left(R^{2}=0.988\right)$. 
Table 5 Producer-and consumer-chained index in current prices in Turkey and inflation rates

\begin{tabular}{|c|c|c|c|c|c|c|}
\hline Years & Producer-chained index & Producer index difference & PPI & Consumer-chained index & Consumer index difference & $\mathrm{CPI}$ \\
\hline 2003 & 100.0 & - & 13.9 & 100.0 & - & 18.4 \\
\hline 2004 & 110.9 & 10.9 & 13.8 & 86.2 & -13.8 & 9.3 \\
\hline 2005 & 95.5 & -4.5 & 2.7 & 108.7 & 8.7 & 7.7 \\
\hline 2006 & 95.6 & -4.4 & 11.6 & 104.9 & 4.9 & 9.7 \\
\hline 2007 & 98.6 & -1.4 & 5.9 & 91.1 & -8.9 & 8.4 \\
\hline 2008 & 88.1 & -11.9 & 8.8 & 100.3 & 0.3 & 10.1 \\
\hline 2009 & 108.5 & 8.5 & 5.9 & 111.0 & 11.0 & 6.5 \\
\hline 2010 & 129.9 & 29.9 & 8.9 & 124.1 & 24.1 & 6.4 \\
\hline 2011 & 94.9 & -5.1 & 13.3 & 90.1 & -9.9 & 10.5 \\
\hline 2012 & 82.8 & -17.2 & 2.5 & 96.2 & -3.8 & 6.2 \\
\hline 2013 & 103.6 & 3.6 & 7.0 & 106.0 & 6.0 & 7.4 \\
\hline 2014 & 156.5 & 56.5 & 6.4 & 146.8 & 46.8 & 8.2 \\
\hline 2015 & 84.8 & -15.2 & 5.7 & 101.7 & 1.7 & 8.8 \\
\hline 2016 & 83.9 & -16.1 & 9.9 & 87.7 & -12.3 & 8.5 \\
\hline 2017 & 108.8 & 8.8 & 15.5 & 107.2 & 7.2 & 11.9 \\
\hline
\end{tabular}

Source: Authors' own calculations

Additionally, according to the analysis results, pistachio retail price, income, and walnut retail price parameters' coefficients are adverse to the economics theory.

In the study of Karacan and Ceylan (2017), an analysis on Turkey's amount of pistachio fruit, particularly in Turkey, prices, and growing area of the historical background shows influence along with other non-price factors, affecting the Turkey's Food and Agriculture Organization used by the Statistics Authority. Partial correlation coefficients were observed, together with the amount of pistachio production, price, production area, number of trees, and competitor countries. Periodicity in production, delay of production amount, is seen in negative parameter value. It was understood that $30 \%$ of the production amount of the previous year was variable as the number of trees used experimentally. According to the $F$ statistic, all independent variables together were significant in $99 \%$ assurance.

Özkan et al. (2011) expected production and price for agricultural products can be correlated with the quantity and prices of previous years. Producers are making changes on production decisions considering the realizations of previous years because it is not possible to change the product supply in the same period as the figures of the current year. This also applies to non-price factors. Producers cannot change production decisions when faced with a seasonal price shock, climate change, or legal change. Accordingly, in order to decide the production of the current year, they have to observe the price levels and market movements of the previous years. The supply of single-year agricultural products is a function of the price of the previous year, but pistachios are multi- annual and the production decision cannot be changed. Therefore, it is thought that the production decisions of Pistachio nuts give a hypothetical 1-year delay response. The same approach was used in my study.

According to the study of Dağdemir (1998), in the period from 1975 to 1994, economic analysis study is focused on measuring fluctuations and fluctuations in the price of onions. Marketing margins are calculated according to current and real prices. Producer and consumer chain indexes were calculated according to real prices and compared with annual inflation rates. The relationship between onion production amount and producer real price was examined, and "Cobweb Theorem" was applied to determine cyclical movements. The supply elasticity of De $>$ Se onion was found to be greater than demand elasticity. As a result, angry cobweb has emerged. In pistachio, Se < De was determined.

\section{Conclusion}

According to the pistachio supply and demand functions, supply elasticity is (Se) 0.306, demand elasticity (De) is 1.055. According to the Cobweb theory when the $\mathrm{Se}<\mathrm{De}$, prices approaches to the periphery from the core, cycle moves decreases as the fluctuations shrinks. Consumers' sensibility to price is much more than the producers in the pistachio.

\section{Abbreviations}

TSI: Turkish Statistical Institute; FAO: Food and Agriculture Organization; AEPDE: Agricultural Economic and Policy Development Institute; Se: Supply elasticity; De: Demand elasticity 


\section{Author's contributions}

The author participated in the preparation and analysis of the data and the writing of the article. The author read and approved the last article.

\section{Funding}

Not applicable.

\section{Availability of data and materials}

The author agreed to use the data and materials as reference.

Ethics approval and consent to participate

Not applicable

\section{Consent for publication}

The author authorizes the publication of this article in the NRC newsletter.

\section{Competing interests}

The author declares that he has no competing interests.

Received: 10 September 2019 Accepted: 22 October 2019

Published online: 09 December 2019

\section{References}

Agricultural Economic And Policy Development Institute. (2019) AEPDI https:// arastirma.tarimorman.gov.tr/tepge (date accessed : 25.02.2019) (in Turkish).

Aksoy A, Atsan T, Yavuz F (2002) Econometric Analysis of Pistchio sector in Turkey, Turkey V. Agricultural Economics Congress, 18-20 September, Erzurum (in Turkish).

Altundağ S, Güneş T (1992) Quantity and price relationship of potato and onion in Turkey. Yearbook of Ankara University Agriculture Faculty, Ankara, pp 5265 (in Turkish)

Aşkan E, Dağdemir V (2015) Economic analysis of garlic in Turkey. Alinteri J Agric Sci 28(1):19-26 (in Turkish)

Dağdemir V (1998) Economic analysis of Turkey onion market. J Ataturk University Faculty Economics Administrative Science 12(1/2):99-114 (in Turkish)

Dağdemir V, Birinci A (1999): Effects of marketing potato and price fluctuations on production in Turkey, II. Potato Congress, 28 - 30 June, Erzurum, (in Turkish).

Ertürk YE, Geçer MK, Gülsoy E, Yalçın S (2015) Pistachio Production and Marketing. J Iğdır Univ Inst Sci 5(2):43-62 (in Turkish)

Food and Agriculture Organization. (2019) FAO http://www.fao.org/faostat/en/ \#data/QC, (date accessed: 19.02.2019).

Karacan E, Ceylan FR (2017) The analysis of the effect of pistachio price on the decision of producers, Kastamonu University Journal of Faculty of Economics and Administrative Sciences- Volume 18, Issue 1, ICEBSS 2017 Special Issue. (in Turkish)

Özkan B, Ceylan F, KIzlay H (2011) "Supply response for wheat in Turkey: a vector error correction approach". Mediterranean Journal of Economics, Agriculture and Environment, 3/2011, pp: 34-38. https://pdfs.semanticscholar.org/d95 7/310013609feb7e993aaa81e2b53baa429a4e.pdf

Pistachio Sector Report, Republic of Turkey Ministiry of Trade (2016). RTMT https://ticaret.gov.tr/data/5b8700a513b8761450e18d81/Antep_Fistigi.pdf, (Date accessed: 15.02.2019), (in Turkish).

Republic of Turkey Ministry of National Education. (2015) RTMNE Agriculture, Nuts, http://megep.meb.gov.tr/mte_program_modul/moduller/Sert\%2 OKabuklu\%20Meyveler.pdf, (date accessed: 20.02.2019). (in Turkish)

Topcu Y (2003) Marketing margin in food products and algebraic analysis, Atatürk Univ J Agric Fac. 34 (2): 199-207, (in Turkish). https://dergipark.org.tr/ $\mathrm{tr} /$ pub/ataunizfd/issue/2945/40814

Topcu Y (2004) A study on the meat cost and marketing margins of cattle fattening farms in Erzurum Province. Turkish Journal of Veterinary and Animal Sciences, 28(6): 1007-1015. (in Turkish). https://dergipark.org.tr/tr/pub/ tbtkveterinary/issue/12547/151443

Turkish Statistical Institute. (2019) TSI Plantal Production Statistics, http://www. tuik.gov.tr/PreTablo.do?alt_id=1046 (Date accessed: 06.02.2019), (in Turkish).

\section{Publisher's Note}

Springer Nature remains neutral with regard to jurisdictional claims in published maps and institutional affiliations.

\section{Submit your manuscript to a SpringerOpen ${ }^{\circ}$ journal and benefit from:}

- Convenient online submission

- Rigorous peer review

- Open access: articles freely available online

High visibility within the field

- Retaining the copyright to your article

Submit your next manuscript at $\boldsymbol{\nabla}$ springeropen.com 